\title{
PROBLEMI NEFORMALNIH (OBITELJSKIH) NJEGOVATELJA U SKRBI ZA OSOBE S DEMENCIJOM - KVALITATIVNI PRISTUP
}

\author{
ANA TILINGER ${ }^{1}$, ANA ŠTAMBUK ${ }^{2}$ \\ ${ }^{1}$ Centar za socijalnu skrb Požega, ${ }^{2}$ Sveučilište u Zagrebu, Pravni fakultet, Studijski centar socijalnog rada, Zagreb, \\ kontakt: astambuk@pravo.hr
}

Primljeno: 04.05.2018.

Prethodno priopćenje

Prihvaćeno: 02.10.2018.

UDK 36447:616.831056.24

https://doi.org/10.31299/hrri.54.2.6

\begin{abstract}
Sažetak: Alzheimerova bolest, kao najčešći oblik demencije, progresivna je, neizlječiva i može dovesti do potpune ovisnosti o drugima. U vrlo je teškom položaju obitelj, odnosno njegovatelj oboljelog koji se susreće s brojnim poteškoćama. Preuzimanjem zahtjevne uloge skrbi o članu obitelji njegovatelj često postaje “žrtvom bolesti” koja treba iznaći načine nošenja sa svime što bolest donosi. Inozemna istraživanja pokazuju da neke provedene intervencije pomažu njegovateljima u njihovoj ulozi kao što su: znanje o procesu bolesti, znanje o prehrani i njezi oboljele osobe, znanje o kontroli stresa povezanog s ulogom njegovatelja te upute kako rješavati probleme povezane s pacijentovim promijenjenim ponašanjem. Kako bismo dobili uvid u probleme s kojima se susreću neformalni njegovatelji u skrbi o članu obitelji oboljelom od demencije kod nas, ispitali smo njihova iskustva. Za provedbu kvalitativnog istraživanja korišten je polustrukturirani intervju. Rezultati ovog istraživanja ukazuju da su neformalni njegovatelji suočeni sa zahtjevnim zadacima njegovateljske uloge, otežanom komunikacijom s oboljelim, problemima na razini sustava, socijalnom izolacijom te narušenim psihofizičkim funkcioniranjem. U radu je istaknuta važnost edukacije neformalnih njegovatelja o različitim aspektima njege s ciljem da se olakša njegovateljska uloga, kao i stručnjaka koji rade s oboljelima te informiranje i senzibilizacija lokalne zajednice i društva o potrebama neformalnih njegovatelja.
\end{abstract}

Ključne riječi: Alzheimerova bolest, demencija, obitelj, neformalni njegovatelji

\section{UVOD}

Demografske promjene, a prije svega starenje stanovništva, najznačajniji su trend posljednjih nekoliko desetljeća u razvijenim europskim zemljama, među kojima je i Hrvatska. S jednim od najvećih udjela starijeg stanovništva u Europi $(17,7 \%)$ Hrvatska se svrstava među deset zemalja u svijetu s najstarijim stanovništvom (Jedvaj i sur., 2014). Promjene koje donosi proces starenja, kao što su odlazak u mirovinu, funkcionalna nesposobnost, povećani rizici od bolesti i invalidnosti, financijska ovisnost, socijalna isključenost, gubitak bliskih osoba i slično, rezultiraju potrebom starih ljudi za potporom obitelji, zajednice, ali i organiziranim mjerama lokalne i šire društvene zajednice (Žganec i sur., 2008). To je ujedno i populacija koja najčešće obolijeva od demencije (Puljak i sur, 2005).
Folnegović-Šmalc i suradnici (2002) definiraju demenciju kao klinički sindrom uzrokovan bolešću mozga, obično kroničnog ili progresivnog tijeka sa stečenim višestrukim oštećenjem viših kortikalnih funkcija uključujući pamćenje, mišljenje, shvaćanje, rasuđivanje, orijentaciju, sposobnost učenja, jezik i računanje. Kognitivna oštećenja obično su praćena pogoršanjem emotivne kontrole, socijalnog ponašanja i motivacije. Danas je poznato više od 50 bolesti koje mogu uzrokovati demenciju, od kojih je najčešća Alzheimerova bolest na koju otpada oko dvije trećine svih demencija. U Hrvatskoj ne postoji registar oboljelih od Alzheimerove demencije, ali se procjenjuje da ima oko 80.000 oboljelih i da će ova brojka rasti (Mimica i Presečki, 2010). U svijetu oko 50 milijuna ljudi ima demenciju, a svake godine obolijeva oko 10 milijuna novih (WHO, 2017). Demencija je tipična bolest starije populacije, pa se tako znatno 
češće javlja nakon 65 . godine života uz naznaku da njena pojavnost bitno raste s porastom životne dobi pojedinca. Alzheimerova bolest i druge demencije utječu prvenstveno na kvalitetu života oboljelih, ali utječu na mnoga područja njegovatelja. Stoga je u svibnju 2017. godine Svjetska zdravstvena organizacija donijela Globalni akcijski plan o javnozdravstvenom odgovoru na demenciju 2017-2025 (WHO, 2017). Plan pruža sveobuhvatni nacrt djelovanja za donositelje politike, međunarodne, regionalne i nacionalne partnere i SZO na područjima kao što su: povećanje svijesti o demenciji i osnivanje inicijativa koje pogoduju demenciji; smanjenje rizika od demencije; dijagnoza, liječenje i njega; istraživanje i inovacije te podrška za skrbnike osoba oboljelih od demencije. Osnovna je značajka Alzheimerove bolesti polagan početak i napredovanje bolesti s pogoršanjem postojećih te $\mathrm{s}$ javljanjem novih simptoma zbog sve većeg propadanja moždane kore bez određenog razloga (Barac, 1992; prema Škrbina i Radić, 2010). Oboljeli je na početku bolesti najčešće svjestan svoje nemoći, bez mogućnosti objašnjenja svih novih simptoma bolesti i razumijevanja istih, što kod njega izaziva strah, depresivnost, uznemirenost, a često i agresiju. U uznapredovanom stadiju bolesti bolesnik se ne sjeća imena rođaka i bliskih osoba, ne prepoznaje ih, ne uočava ili ne razumije rodbinske $i$ prijateljske relacije, njihova zanimanja i funkcije $\mathrm{u}$ društvu; zaboravlja vlastito ime te praznine $\mathrm{u}$ sjećanju nadomješta konfabulacijama. Kad smetnje pamćenja postanu sve izraženije, nastaju i drugi poremećaji kognitivnih sposobnosti. Bolesnikov govor postaje usporen zbog nedostatka pronalaženja odgovarajućih riječi, a slično se događa i prilikom pisanja. Osim toga ukupni rječnik znatno je smanjen, a govor postaje stereotipan i siromašan (Poredoš, 2003). Snalaženje u prostoru postaje otežano. Nadalje vidljivi su poremećaji prosuđivanja i ponašanja. Kako bolest napreduje, osoba prestaje adekvatno obavljati aktivnosti svakodnevnog života, bilo da se radi o aktivnostima samozbrinjavanja (hranjenje, održavanje osobne higijene), aktivnostima produktivnosti (nerazumne odluke u poslu, zanemarivanje održavanja domaćinstva) ili aktivnostima slobodnog vremena (manjak ili osiromašenje interesa te motiva za uključenje). S vremenom postaju vidljive poteškoće i u motoričkom statusu oboljelog, pa je tako vidljiv tremor ruku, usporenost pokreta, slabije izražene mišićne reakcije te teškoće motoričkog planiranja. U uznapredovanom stadiju bolesti dolazi i do gubitka kontrole sfinktera te na samom kraju osoba postaje nepokretna, a bolest završava smrću (Laklija i sur. 2009). Karakter bolesti polako narušava svakodnevni život oboljeloga, no jednako snažno utječe i na život obitelji, odnosno neposrednog njegovatelja. Obitelj kao osnovna jezgra skrbi, čini najveći resurs u njezi za osobu oboljelu od demencije kada ona više nije u mogućnosti učinkovito skrbiti o sebi (Laklija i sur., 2009). Obitelj je više od biološke veze, njezini mehanizmi prilagodbe omogućavaju da se bolest člana prihvati kao ključni dio života obitelji (Rapić i sur., 2014). Osobe s demencijom općenito zahtijevaju visoku razinu skrbi, od kojih je većina predviđena neformalnom ili obiteljskom njegom. Bez njegovatelja osobe s demencijom imat će lošiju kvalitetu života i trebaju institucionalnu skrb. U Hrvatskoj su usluge skrbi za starije osobe dosta nerazvijene, pa tako i za ovu populaciju koja ima vrlo specifične potrebe i zahtijeva najčešće dugotrajnu i cjelodnevnu skrb. Stoga teret skrbi za starije osobe najčešće preuzimaju supružnik i odrasla djeca, odnosno neformalni njegovatelji (Podgorelec, Klempić, 2007). Premda je srednja dob najproduktivnije i najmirnije razvojno razdoblje u kojem čovjek postiže punu snagu, ipak treba napomenuti da je to generacija u "sendviču", jer često istodobno mora pomagati vlastitoj djeci i unucima, kao i ostarjelim roditeljima (Schaie, Willis, 2001: 54).

Obitelj je suočena s potrebom da promijeni vlastiti život i prilagodi ga potrebama oboljele osobe. Najprije je potrebno prilagoditi uvjete stanovanja budući da Alzheimerova bolest dovodi do slabije pokretljivosti i usporenosti pa je nužno napraviti neke prostorne promjene (Poredoš, 2003). Skrb i njega u obitelji za osobe oboljele od demencije često nosi sa sobom narušeno fizičko i psihičko zdravlje njegovatelja kao i financijske probleme (Bastawrous, 2013; Etters, Goodall \& Harrison, 2008). Njegovatelji često ističu i dobrobiti koje proizlaze iz njihove uloge, prije svega radost što se mogu brinuti o svom članu obitelji (najčešće supruzi odnosno majci) te njegovateljsko iskustvo opisuju kao ono koje je obogatilo kvalitetu njihova života (Sorrell, 2006). 
U početku bolesti više pati pojedinac, a u kasnijim fazama, kada mentalna kontrola oslabi i bolest okupira osobu, smatra se da više pati obitelj, odnosno njegovatelj (Poredoš, 2003). Usporedno s prelaskom iz niže u višu fazu bolesti, zamijećen je trend smanjenja socijalnih kontakata oboljelog i njegove obitelji, što dovodi do novih tenzija među članovima obitelji, pa čak i do raspadanja obiteljskih mreža (Chenoweth i Spencer, 1986; Wilson 1989; Commissaris, 1995, prema Laklija i sur. 2009). Brodaty i Donkin (2009) ističu kako su najjači prediktori njegovateljskog stresa za skrbnika sljedeći: "uloga zatočenika" (njegovateljev osjećaj da je "zarobljen" u svojoj ulozi), preopterećenje njegovatelja (npr. umor i izgaranje) te nepovoljni životni događaji izvan uloge njegovatelja.

\section{Intervencije koje pomažu njegovateljima u skrbi}

Neka istraživanja pokazuju da znanje o procesu bolesti demencije utječe na bolje donošenje odluka i nižu razinu depresije kod njegovatelja, odnosno smanjuje njegovateljski teret (Scott, 2013). MartínCarrasco i suradnici (2009) proveli su evaluaciju Programa psihoedukativnih intervencija za njegovatelje osoba s demencijom. Naglasak u edukaciji stavljen je na informacije o tijeku bolesti, kako kontrolirati stres vezan uz odgovornosti za njegu, strategije za rješavanje problema ponašanja pacijenata kao i povećanje zadovoljstva životom unatoč novoj ulozi u kojoj se nalaze. Istraživači su pronašli statistički značajno smanjenje tereta njegovateljske uloge u odnosu na skupinu koja nije prolazila edukaciju. Rezultati su pokazali da 97,7\% njegovatelja smatra da im je Program koristio neposredno nakon samog završetka edukacije, dok 93,2\% ispitanika smatra da je Program bio koristan i nakon što je prošlo 10 mjeseci od edukacije. Edukacijski program "Powerful Tools for Caregivers" (Osnažujući alati za njegovatelje) koji je proveo Savundranayagam i suradnici (2011) uključivao je šest tjednih sastanaka koji su bili fokusirani na izazove zbrinjavanja, brigu o vlastitom zdravlju, upravljanje stresom, komunikacijske vještine, bavljenje emocijama kao što je krivnja i kako donositi teške odluke povezane s njegom oboljele osobe. Polaznici ovog programa imali su značajno niži njegovateljski stres i niži objektivni teret njege $\mathrm{u}$ odnosu na kontrolnu skupinu. Puljak i suradnici (2005) ističu kako je uz kontinuiranu senzibilizaciju javnosti i stručnjake s ovog područja edukaciju putem medija, tiska, radionica, ali i edukaciju organiziranu kroz gerontološke centre - potrebno i poboljšanje dnevne skrbi.

Ovim istraživanjem željeli smo od neformalnih njegovatelja čuti s čim se suočavaju u svojoj njegovateljskoj ulozi, pri čemu smo koristili kvalitativni pristup. Naime u istraživanjima njegovatelji često navode kako prije nisu imali priliku s nekim podijeliti svoju "priču" (Sorrell, 2006). U Hrvatskoj je ova tema malo istražena iako su predviđanja da će do 2050. broj oboljelih od demencije biti učetverostručen (Mimica i Presečki, 2010). Stoga je jedan od doprinosa ovog istraživanja dobivanje uvida $u$ specifične probleme s kojima se susreću obiteljski njegovatelji osoba s demencijom kod nas te uvažavanje njihovih iskustava $u$ razvoju strategija $i$ osmišljavanju intervencija.

\section{CILJ ISTRAŽIVANJA}

Cilj ovog istraživanja bio je stjecanje uvida $u$ iskustvo neformalnih (obiteljskih) njegovatelja $u$ skrbi za osobe s demencijom.

Sukladno cilju istraživanja postavili smo istraživačko pitanje: S kojim se problemima susreću neformalni njegovatelji skrbeći o osobama s demencijom?

\section{METODA}

\section{Sudionici istraživanja}

Ciljana populacija istraživanja bili su neformalni (obiteljski) njegovatelji osoba oboljelih od demencije. Za ovo istraživanje odabrana je neprobabilistička metoda uzorkovanja, točnije namjerni uzorak. Prema Milasu (2005) namjerni uzorak prilagođen je posebnim istraživačkim ciljevima pri čemu se uzorak odabire na temelju nekih prethodnih spoznaja o populaciji. Kontaktirale smo ustanove na području grada Zagreba koje pružaju dnevnu skrb osobama oboljelim od demencije (Dnevni centri). Preko tih ustanova došli smo do kontakata neformalnih njegovatelja. Sudionike su najprije kontaktirali socijalni radnici zaposleni u dnevnim boravcima, nakon čega su ih osobno kontaktira- 
li sami istraživači u svrhu konačnog pristanka na intervju te dogovora o mjestu i vremenu njegova provođenja. Kriterij za sudjelovanje u istraživanju bio je da su njegovatelji minimalno dvije godine brinuli o svom članu obitelji te da su dobrovoljno pristali na intervju. Istraživač je posjedovao znanja i iskustva iz područja socijalne gerontologije te specifičnostima komunikacije sa starijim osobama u vođenju intervjua. Ukupno je sudjelovalo 10 neformalnih njegovatelja, od kojih je devet žena te jedan muškarac. Svi su sudionici u rodbinskom odnosu sa osobom oboljelom od demencije (tri supruge, šest kćeri i jedan sin). Prosječna je dob ispitanika 58 godina, najmlađi ispitanik ima 30 godina, a najstariji 70 . Duljina skrbi o osobi oboljeloj od demencije u rasponu je od 2 do 10 godina. Što se obrazovnog statusa tiče, osam je visokoobrazovanih, a dvoje ima srednju stručnu spremu. Šest je ispitanika u radnom odnosu, troje u mirovini, a jedan je ispitanik nezaposlen.

\section{Metoda prikupljanja podataka}

Za metodu prikupljanja podataka izabran je polustrukturirani intervju. Ta je metoda odabrana radi svoje fleksibilnosti jer osigurava ravnotežu između strukture pitanja i otvorenosti odgovora (Gillham, 2005). Tijekom provođenja polustrukturiranog intervjua istraživač je imao listu s dvanaest pitanja kojima se vodio u svom ispitivanju. Pitanja su bila otvorenog tipa te su ispitanici mogli o odgovarati na pitanja $i$ opisivati svoja iskustva vezana uz ulogu njegovatelja. Također su postavljena pitanja o sociodemografskom statusu (dob, spol, rodbinski odnos s oboljelom osobom, stupanj obrazovanja, radni status, duljina skrbi o oboljeloj osobi).

\section{Postupak prikupljanja podataka}

Istraživanje je provedeno na području Grada Zagreba. Za način vođenja bilješki, odnosno bilježenja odgovora ispitanika, koristio se diktafon. Od svakog ispitanika dobiven je pristanak te je pojašnjeno da će nakon analize podataka snimani materijal biti uništen. Sudionicima istraživanja objašnjen je cilj istraživanja i naglašeno je da je istraživanje anonimno te da će rezultati biti korišteni u znanstvene svrhe. Prilikom provedbe intervjua poštovana su temeljna načela istraživačke etike te su sudionici mogli u svakom trenutku odustati od istraživanja. Za vrijeme intervjuiranja sudionici su bili zamoljeni da uklone moguće distraktore kako bi se mogli fokusirati na pitanja. Svi ispitanici koji su pristali na intervju izrazili su zadovoljstvo sudjelovanjem. Intervju je u prosjeku trajao oko 25 minuta.

\section{Kvalitativna analiza podataka}

U ovom istraživanju odabran je kvalitativni pristup budući da, kako navodi Milas (2005), kvalitativna istraživanja pomažu istraživaču da se usmjeri na ono što ispitanicima doista znači kritičnu točku koju treba ispitati te nudi razumijevanje pojave isključivo na pojedinačnim slučajevima ili manjim skupinama srodnih pojedinaca. Ono što Milas (2005) dalje navodi kao obilježje kvalitativnog pristupa, a što se povezuje i s ovim istraživanjem, jest činjenica da se kvalitativne metode temelje na analizi tekstualne građe nastale na temelju osobnih iskustava, životnih priča, pojedinačnih i skupnih intervjua, opažanja i svih drugih dokumenata koji opisuju podjednako svakodnevne i izuzetne trenutke značajne za život pojedinca. Snimljeni razgovori pretvoreni su u transkripte intervjua te su nakon toga podaci obrađeni kroz nekoliko koraka uporabom postupka kvalitativne analize sadržaja. Vrsta obrade podataka koja se koristila bila je "tematska analiza podataka" (Braun i Clarke, 2006). Budući da se problemi neformalnih njegovatelja mogu manifestirati u vrlo različitim temama ovisno o percepciji pojedinca, induktivnim pristupom nastojalo se dobiti produbljivanje teme na neka područja koja ne bi mogla biti unaprijed određena. Obrada podataka nakon izrade transkripta uključivala je: čitanje transkripta i bilježenje onih dijelova koji predstavljaju odgovor na odabrana istraživačka pitanja $\rightarrow$ traženje zajedničkih tema koje proizlaze iz sličnosti sadržaja i pripisivanje kodova tim temama $\rightarrow$ grupiranje sadržajno sličnih tema i definiranje istih $\rightarrow$ provjera odgovaraju li kodovi i teme istraživačkim pitanjima $\rightarrow$ izrada tematske mape (Braun i Clarke, 2006).

\section{REZULTATI I RASPRAVA}

Problemi neformalnih njegovatelja u skrbi za članove obitelji oboljele od demencije prikazani su kroz šest tema: zahtjevnost njegovateljske uloge, 
otežana komunikacija s oboljelim, nedovoljna osviještenost okoline o bolesti, neorganiziranost sustava, socijalna izolacija i narušeno psihofizičko funkcioniranje njegovatelja. Radi lakšeg praćenja rezultata istraživanja, sve teme i kategorije prikazane su u Tablici 1 te dalje komentirane u tekstu koji slijedi.

Tablica 1. Problemi u skrbi za osobe oboljele od demencije

\begin{tabular}{|c|c|}
\hline \multicolumn{2}{|c|}{$\begin{array}{l}\text { TEMATSKO PODRUČJE: } \\
\text { PROBLEMI U SKRBI ZA OSOBE OBOLJELE OD } \\
\text { DEMENCIJE }\end{array}$} \\
\hline Teme & Podteme \\
\hline \multirow{3}{*}{$\begin{array}{l}\text { 1. Zahtjevnost/ } \\
\text { okupiranost } \\
\text { njegovateljskom } \\
\text { ulogom } \\
\end{array}$} & 1. Cjelodnevna briga/skrb \\
\hline & 2. Dodatne kućanske obaveze \\
\hline & 3. Sukob uloga \\
\hline \multirow{2}{*}{$\begin{array}{l}\text { 2. Otežana } \\
\text { komunikacija s } \\
\text { oboljelim }\end{array}$} & 1. Razgovor o besmislenim temama \\
\hline & 2. Nemogućnost sporazumijevanja \\
\hline \multirow{2}{*}{$\begin{array}{l}\text { 3. Nedovoljna } \\
\text { osviještenost o } \\
\text { bolesti }\end{array}$} & 1. Nedovoljna educiranost \\
\hline & 2. Nedostatak senzibiliteta okoline \\
\hline \multirow{3}{*}{$\begin{array}{l}. \\
\text { Neorganiziranost } \\
\text { sustava }\end{array}$} & $\begin{array}{l}\text { 1. Nemogućnost institucionalnog } \\
\text { smještaja }\end{array}$ \\
\hline & $\begin{array}{l}\text { 2. Nemogućnost dobivanja stručne } \\
\text { pomoći/ podrške }\end{array}$ \\
\hline & 3. Nedovoljna educiranost stručnjaka \\
\hline \multirow[t]{3}{*}{$\begin{array}{l}\text { 5. Socijalna } \\
\text { izolacija }\end{array}$} & $\begin{array}{l}\text { 1. Nedostatak vremena za slobodne } \\
\text { aktivnosti }\end{array}$ \\
\hline & 2. Manjak vremena za prijatelje \\
\hline & 3. Manjak vremena za obitelj \\
\hline \multirow{4}{*}{$\begin{array}{l}\text { 6. Narušeno } \\
\text { psihofizičko } \\
\text { funkcioniranje } \\
\text { njegovatelja }\end{array}$} & 1. Njegovateljski stres \\
\hline & 2. Sagorijevanje \\
\hline & 3. Problemi sa spavanjem \\
\hline & 4. Narušeno tjelesno zdravlje \\
\hline
\end{tabular}

1. Zahtjevnost/okupiranost njegovateljskom ulogom očituje se kroz cjelodnevnu brigu o bolesnoj osobi, dodatnim kućanskim obavezama i sukobu uloga. Bolest pogađa sve aspekte života osobe, njezine vještine i obavljanje aktivnosti dnevnog života. Karakter bolesti jednako snažno utječe i na život obitelji ili skrbnika (Puljak i sur., 2005). U obitelji koja sudjeluje u pružanju skrbi, jedan njezin član tj. ključna osoba preuzima na sebe veći dio svakodnevne njege bolesnika koja varira od jednostavnih postupaka do kompletne njege koja zahtjeva savladavanje određenih vještina koje članovi obitelji do tada nisu imali (Rapić i sur., 2014).
Kako bolest napreduje, oboljeli prestaje samostalno obavljati aktivnosti svakodnevnog života, bilo da se radi o aktivnostima samozbrinjavanja (hranjenje, održavanje osobne higijene), aktivnostima produktivnosti (nerazumne odluke u poslu, zanemarivanje održavanja domaćinstva) ili aktivnostima slobodnog vremena (manjak ili osiromašenje interesa te motiva za uključenje). S vremenom postaju vidljive poteškoće i u motoričkom statusu oboljelog (tremor ruku, usporenost pokreta, slabije izražene mišićne reakcije i teškoće motoričkog planiranja, Laklija i sur. 2009). Zahtjevnost/okupiranost njegovateljskom ulogom, kako navode neformalni njegovatelji, ogleda se i u cjelodnevnoj brizi za oboljelog: Ma što 24, 48 sati na dan radim!? Jedna osoba naprosto nije dovoljna jer jedna osoba treba samo za nju skrbiti, a druga treba obaviti nešto izvan kuće jer ju samu ne mogu ostaviti.(I1); Bez obzira da li se radilo o hiperekscitiranosti ili o tom nekakvom "potonuću" šta jesu dvije krajnosti između koje ona oscilirala, definitivno treba 24-satnu brigu. (I3); ...ako si sa takvom osobom, ti moraš biti posvećen samo njoj a sebe staviti u plan B. Ne možeš apsolutno ništa raditi, čak ne znaš da li ćeš imati vremena za spavanje. (I2). Budući da su usluge skrbi i podrške u zajednici za osobe oboljele od Alzheimerove bolesti još uvijek nedovoljno razvijene u Hrvatskoj, teret skrbi najčešće preuzimaju supružnik i/ili odrasla djeca (Laklija i sur., 2009). Demencija se često povezuje s mnogo sati njege te brojnim fizičkim zahtjevima (Brodaty i Donkin, 2009). Ograničenja koja se mogu javiti kod njegovatelja u skrbi za oboljelu osobu jesu: količina vremena provedenog u skrbi, potreba za uspostavom ravnoteže između zaposlenja i skrbničkih aktivnosti, fizičke poteškoće u kretanju obolje$\log$, pitanje dostojanstva i privatnosti njegovatelja i oboljele osobe prilikom obavljanja skrbničkih radnji (npr. promjena pelena, pomoć prilikom tuširanja ili obavljanja drugih fizioloških potreba itd.) (Laklija i sur., 2009). Dosadašnja istraživanja pokazuju da su skrbnici tri četvrtine dana posvećeni skrbi za oboljelog, dok udio vremena provedenog u skrbi pokazuje trend linearnog povećanja kako bolest napreduje (Aguglia i sur., 2000). Istraživanje Leona (1998., prema Laklija i sur., 2009) pokazalo je da su zaposlene žene u nekim slučajevima čak prisiljene otići u mirovinu kako bi skrbile o supružniku. Osim toga u istraživanju Rusac i suradnica 
(2012), rezultati pokazuju da su ispitanici visoko opterećeni zahtjevima dnevne skrbi o oboljelom. I u ovom istraživanju neformalni njegovatelji obavljanje dodatnih kućanskih obaveza smatraju zahtjevnim zadatkom nove njegovateljske uloge: Sve više sam doma da mogu skuhati jer ako ja ne stignem skuhati, ona neće skuhati ni jesti, jer se sama ne sjeti.(I5); ...Sve kućanske poslove na sebe sam preuzeo, ona mi je prije u tome pomagala, npr. rezati luk ili čistiti salatu i takve nekakve stvari... (I6); Jedan dio poslova je bio na njemu i najednom sav taj posao je ostao na meni. I briga oko auta i briga oko svega. (I8); Nije nimalo lako brinuti se stalno o njoj. (I10). Njegovatelji srednje dobi često se nalaze u sendviču između skrbi za roditelje i odgovornosti prema djeci, poslu i slično. Zbog navedenog teže se nose sa zahtjevima dnevnih aktivnosti (ustajanje iz kreveta i stolice, oblačenje, kupanje/tuširanje, nošenje s poteškoćama vezanim uz inkontinenciju i hranjenje) (Dang, 2008; prema Rusac i sur., 2012). Njegovateljske dnevne aktivnosti dovode znatno više do narušavanja mentalnog zdravlja njegovatelja za razliku od fizičkih sposobnosti koje ostaju duže očuvane. Osim toga zahtjevnost njegovateljske uloge ogleda se i u sukobu uloga koju doživljavaju neformalni njegovatelji. Pa, strašno teško, strašno teško. To je bitka u kojoj sam izgubila. Mislim, brinuti se o roditelju koji se brinuo o vama, a niste to u stanju, jako je teško. To je prestrašno. Prestrašno.... a možda najveća količina suza je bila kad me ona više nije prepoznavala. Sada sam ja njezina majka, a ona moja kćer. (I1); ...teško je kada vidite osobu koja je skrbila o vama, a sada joj je potrebna totalna skrb. To je na razini, pa čak ne bih rekla ni četverogodišnjeg djeteta. Morate apsolutno sve imati pod kontrolom. (I2); ...s njom se ujutro moram dogovoriti šta će obući. To sam ja sa svojom djecom radila kad su bila mala.(I3); Znate, kao da imate malo dijete, vi se od malog djeteta ne možete odvojiti. Ili otac ili majka mora biti s djetetom.(I10); pa prije svega ta odgovornost za osobu koja bi se trebala sama moći brinuti o sebi, a sad ona mene zove mama. (19). Brodaty i Donkin (2009) ističu kako se pružatelji skrbi suočavaju s mnogo prepreka kao što su ravnoteža njege s drugim zahtjevima, uključujući i podizanje djece, karijere i sl. Sukob uloga koje osoba doživljava suočena s brigom za onemoćalog roditelja može izazvati snažne ambivalentne osje- ćaje koji proizvode depresivne simptome (Marks, Lambert i Chiu, 2002. prema Čudina-Obradović i Obradović, 2006).

2. Za neformalne njegovatelje osoba oboljelih od demencije, značajan problem u skrbi predstavlja i otežana komunikacija s oboljelom osobom koja se manifestira kroz razgovor o besmislenim temama i nemogućnost sporazumijevanja. Razgovor o besmislenim temama potkrepljuju sljedeće izjave ispitanika: Jako je teško biti sugovornik takvoj osobi... tako da ona nekad ima površne kontakte... Razgovor s mojom mamom svodi se na besmislene teme. (I2); Ponekad u razgovoru izvlačiš riječ po riječ, a ponekad se stalno ponavlja, vrti u krug jedno te isto (I5). Isto tako otežana komunikacija s oboljelom osobom ogleda se i u nemogućnosti sporazumijevanja: ...Pa najteže mi bude kad on odluta u tu svoju demenciju $i$ kad mu ne mogu nešto dokazati ili kad mu nešto tri puta kažem i on ostane kod svoga, a nije toga svjestan. (I8).; ...ta je komunikacija svedena na relativno slabo artikuliranje želja i potreba. (I10); Najteže mi pada kad primjećujem da ona pada u depresiju ili da mi pokušava nešto reći, a da ja to ne mogu razumjeti. To mi je strašno teško. (I10). Komunikacija je most koji nas povezuje sa zajednicom u kojoj živimo i djelujemo. Gubljenje sposobnosti komunikacije može biti jedan od težih problema za osobe oboljele od Alzheimerove bolesti i njihovu obitelj (Škrbina i Radić, 2010). Razvojem bolesti osoba doživljava postupno smanjenje mogućnosti komunikacije. U uznapredovanom stadiju bolesnik se ne sjeća imena rođaka i bliskih osoba, ne prepoznaje ih, ne uočava ili ne razumije rodbinske i prijateljske veze, njihova zanimanja i funkcije u društvu; zaboravlja vlastito ime te praznine u sjećanju nadomješta konfabulacijama (Poredoš, 2003). Komunikacijski problemi osoba oboljelih od Alzheimerove bolesti često su vrlo složeni te se mogu pojaviti u različitim oblicima: problemi s pronalaženjem adekvatnih riječi, problemi s izražavanjem i recepcijom govora, siromašan vokabular, eholalija, afazija. Nedostatak, odnosno poteškoće verbalne i neverbalne komunikacije dovode do socijalne deprivacije i otuđenja osobe u svim fazama Alzheimerove bolesti (Škrbina i Radić, 2010).

3. Nedovoljna osviještenost o bolesti predstavlja dodatnu poteškoću s kojom se suočavaju 
neformalni njegovatelji. Naime Alzheimerova bolest postaje jedan od vodećih gerontoloških javnozdravstvenih problema u svijetu te bi zbog toga socijalna osviještenost o ovoj bolesti trebala biti sastavni dio svakog društva u smislu informiranja o prepoznavanju simptoma bolesti i pružanju podrške članovima obitelji (WHO, 2017). Nedovoljnu educiranost prepoznajemo u sljedećim izjavama: Meni smeta što se malo zna o tome. (I8); Problem je što mi kao društvo jako malo znamo o toj bolesti. (I2); .ja nisam ništa znala o Alzheimeru dok se moja mama nije razboljela. (I3). Ove navode potkrepljuju Puljak i suradnici (2005.) koji ističu kako jedan od problema u skrbi predstavlja needuciranost osoba srednje životne dobi, a to je ona populacija koja uglavnom skrbi o starijim osobama u obitelji i može primijetiti prve simptome bolesti, a koja je izrazito zainteresirana za moguća rješenja, pomoć i prilagodbu svakodnevnoga života kada do bolesti dođe. Također nedostaje informiranost o mogućnostima skrbi, samopomoći i pomoći u svakodnevnomu životu oboljeloga i njegove obitelji, kao i o aktivnostima koje mogu usporiti bolest. Naime pomoć obitelji u skrbi za oboljele od Alzheimerove bolesti izuzetno je važna jer se pokazalo kako je burn out sindrom skrbnika često snažnija indikacija za institucionalizaciju nego što je sama težina bolesti. Posljedice neinformiranosti/ needuciranosti u konačnici dovode do neadekvatne skrbi, prerane institucionalizacije bolesnika, brže progresije bolesti te rasta gerijatrijske potrošnje zdravstvene i socijalne zaštite. Obitelji koja skrbi o oboljelome edukacija pomaže u organiziranju skrbi te u prilagodbi na nov način života, počevši od praktičnih stvari kao što su prilagođavanje životnog prostora, osposobljavanja za primjerenu komunikaciju s oboljelim, pomoć u održavanju kognitivnih sposobnosti, sprečavanju "sindroma lutanja" te orijentiranja u vremenu i prostoru (Puljak i sur., 2005). Budući da je okolina, kao i sami njegovatelji, vrlo često neinformirana o bolesti, to dovodi do nedostatka senzibiliteta okoline za obitelj koja je suočena s bolešću. U prilog tome govore sljedeće izjave njegovatelja: I neosjetljivost i osude okoline doživljavam. (11); ... Boli me nerazumijevanje $i$ društva i pojedinaca, šire i uže okoline... (I2); ... društvo nas marginalizira... (I8); Ma društvo uopće nema osjećaja za njih ni za nas, nikoga nije briga. (10). Dio rješenja nalazi se u sustavnoj informi- ranosti javnosti kroz prikaz zahtjevnosti skrbi o oboljelom, u destigmatiziranju bolesnika, o tijeku bolesti i prilagodbi svakodnevnoga života obitelji i oboljeloga. Kako bi se usporilo napredovanje bolesti, oboljeli treba biti integriran u zajednicu te raditi na održavanju preostalih sposobnosti. $\mathrm{Na}$ ovaj način bolesniku se poboljšava kvaliteta života, osjećaj smisla i mogućnost funkcioniranja u svakodnevnome životu, a smanjuju se izolacija i stigmatizacija.

4. Neformalni njegovatelji u skrbi za osobu oboljelu od demencije suočavaju se i s problemima na razini sustava, što se očituje u nemogućnosti nalaženja institucionalnog smještaja, nemogućnost dobivanja stručne pomoći/podrške i nedovoljne educiranosti stručnjaka. U Hrvatskoj ne postoji dovoljno specijaliziranih programa unutar zdravstvenog i socijalnog sustava kojim bi se zadovoljile potrebe oboljelog, njegovatelja i uže obitelji što ima za posljedicu nižu kvalitetu skrbi i života kako oboljele osobe tako i njegovatelja (Rusac i sur., 2012). Problemi vezani uz nemogućnosti nalaženja institucionalnog smještaja oboljelog vidljivi su u sljedećim izjavama njegovatelja: ...nema ustanove koja bi bila adekvatna za njih. (II); Većina domova ne prima oboljele od Alzherimerove bolesti. (I2); Ja mislim da nema u Hrvatskoj neke medicinske ustanove koja se bavi problemima stare populacije. U bolnicama, vidite, postoji pedijatrija, a gerijatrija ne postoji. (I3); Kapaciteti su vrlo mali. (I9); ...ne postoji smještaj za njih... (I10). Poželjno je i za oboljelog najprirodnije što duže ostati u obiteljskom okruženju uz primjerenu skrb i njegu. Kako je demencija karakteristična za osobe starije životne dobi, o oboljelom se najčešće brine bračni partner koji isto može imati određenih zdravstvenih poteškoća. Tako se događa da obiteljska solidarnost s vremenom postaje nedovoljna, te je potreban odgovarajući institucionalni smještaj (Poredoš, 2003). U Hrvatskoj djeluje 46 domova za starije i nemoćne čiji su osnivači jedinice regionalne samouprave te oko 70 domova čiji su osnivači privatne osobe, nevladine ili religijske organizacije ili domaće i strane pravne osobe. Podaci pokazuju da je u domovima za starije i nemoćne smješteno tek oko $2 \%$ populacije starije od 65 godina čemu uvelike pridonosi manjak kapaciteta u domovima kao i relativno visoka cijena. 
Pokrivenost socijalnim uslugama smještajnog tipa dugogodišnji je problem Hrvatske (Žganec i sur., 2008). Postojeći domovi umirovljenika i socijalnozdravstvene ustanove zbog komplikacija simptoma i poremećaja u ponašanju nerado zbrinjavaju osobe s demencijom, budući da je potrebno zaposliti dodatne stručne kadrove. Nemogućnost dobivanja stručne pomoći/podrške također je nešto što neformalni njegovatelji pripisuju problemima na razini sustava: Psihički vas to sve na neki način deprimira jer vidite što vas čeka, jer vidite sebe u budućnosti u jednom sistemu gdje to sve skupa ne funkcionira. Vi trebate psihološku pomoć koje nema, medicinsku pomoć koju također nemate, patronažnu, hospicije $i t d$. To je sve relativno loše organizirano kod nas $i$ onda to, nažalost, sve pada na obitelj da to sama sve rješava i snalazi se kako zna, a to nije dobro. (I3); Nemam se kome obratiti. Nema evidencije uopće. Članovi obitelji nemaju ustanovu kojoj se mogu obratiti. (I6); Vi nemate nekakvu pomoć da bi netko drugi nešto odradio za vas. Morate to sve sami. (I9); Sve vam je to na nekakvoj verbalnoj potpori, ali zapravo stvarnu potporu vi teško možete i očekivati (I10). Osiguranje sustava stručne podrške obiteljskim njegovateljima trebao bi biti, dok se ne razviju druge usluge, minimalni standard u prepoznavanju potreba njegovatelja. Očito je iz navedenih izjava da ove potrebe nisu prepoznate. $U$ prilog ovome govore i rezultati istraživanja Rusac i suradnica (2012). Nadalje nedovoljna educiranost stručnjaka istaknuta je kao problem s kojim se također neformalni njegovatelji suočavaju na razini sustava. Vidi se needukacija... ne zna šta je Alzheimer pa je to proglasila mentalnom bolešću. (I1); Prvo, mi nismo stručne osobe. A jedina stručna pomoć je naš liječnik opće prakse koji isto nije educiran za tu populaciju. (I3); Što meni nitko ne može ništa konkretno i određeno reći, nemam s kime porazgovarati. (I8). U ovom trenutku u Hrvatskoj ne postoji sustavno registriranje ove dijagnoze, pa se Alzheimerova bolest vrlo često krije pod drugim dijagnozama.

5. Neformalni njegovatelji osoba s demencijom često navode da im nedostaje vremena za slobodne aktivnosti, prijatelje i druge članove obitelji što pridonosi osjećaju socijalne izolacije, odnosno njegovatelj ima novi zadatak: promijeniti životni stil, odnosno dotadašnji način života te gotovo sve vrijeme provodi u skrbi za oboljelog člana obitelji (Milić Babić i sur. 2014). Sljedeće izjave odnose se na nedostatak slobodnog vremena: Imam manje vremena za svoj život. Malo je došlo do promjene, pogoršanja, to je istina. Ali ja sam mamu stavila na prvo mjesto. Ona je sad meni najvažnija, pogotovo jer je na kraju života, jer su to visoke godine. (I7); ...puno manje putujemo i naravno puno manje izlazimo. (I9); Ja ne izlazim van, ne idem u kina, kazališta. Moj je izlaz sveden na nekakvih sat vremena jednom tjedno eventualno da obavim nekakav veći šoping. (I10). Pomanjkanje slobodnog vremena, slobode izbora dnevnih aktivnosti obilježja su iskustva vezanih uz skrb o oboljeloj osobu koje nesumnjivo vode u promjenu životnog stila njegovatelja (Milić Babić i sur., 2014). Zanimljiv je podatak kako osobe koje su zadovoljnije svojim društvenim interakcijama pokazuju u manjoj mjeri negativne psihološke simptome (Brodaty i Donkin, 2009). Do socijalne izolacije dolazi i zbog manjka vremena za prijatelje: Pa višse smo izolirani u odnosu na prijatelje. (I4); Socijalni krug, prijateljski, je bio po strani neko vrijeme.(I6); Mi višs ne primamo prijatelje kod kuće nego primamo samo rodbinu i to ono koje mama zna i s kojima se dobro osjeća. Naši prijatelji više ne dolaze jer je to jednostavno postalo prekomplicirano. (I8); Pa, sa prijateljima u tom smisli da oni više ne dolaze kod nas. Ali mi odlazimo njima ili negdje vani, ali puno je rjeđe nego što je prije bilo, doista. (I9); ...jer čim vi nemate mogućnost kretati se, izaći vani, teško vam je družiti se. (I10). Neka istraživanja su pokazala da žene pružaju više skrbi, iskazuju više poteškoća u socijalnim kontaktima te se češće osjećaju usamljenima (Miller, 1992; Skaff i Pearlin, 1992; Beeson, 2000; prema Laklija i sur., 2009). Osim toga Brodaty i Donkin (2009) navode kako se smanjivanjem socijalnog kontakta kod neformalnih njegovatelja povećava osjećaj socijalne izolacije. Uz navedeno do socijalne izolacije dolazi i zbog manjka vremena za članove obitelji: Imam manje vremena za dijete. (I1); Kći više nije ovisna o meni ali suprug je ostao zakinut za tu neku komunikaciju koju bismo nas dvoje htjeli podijeliti... ovako ne stignemo jer nemamo vremena. Ona je sada u prvom planu $i$ onda još $i$ supruga dodatno angažiram da vozi kad treba itd. (I3); ... mamu sam stavila na prvo mjesto a druge sam možda zanemarila. Pa eto, moj muž malo protestira, a s bratom sam malo, promijenjeni su odnosi. (I7); Na kraju krajeva, ipak manje vremena 
provodim sa suprugom nego što sam prije provodila. (I9) Budući da cjelodnevna briga i skrb za oboljelog člana predstavlja potpuno novu organizaciju kako raznih aktivnosti tako i slobodnog vremena, neformalni njegovatelji suočeni su s problemom manjka vremena za obitelj. Tome u prilog govori i podatak kako je usporedno s prelaskom iz niže u višu fazu zamijećen trend smanjenja socijalnih kontakata oboljelog i njegove obitelji, što dovodi do novih tenzija među članovima obitelji, pa čak i do raspadanja obiteljskih mreža (Commissaris, 1995., prema Lakija i sur., 2009). Potreba za sve intenzivnijom skrbi o oboljelom ima izražen negativan utjecaj na njihov život kako na psihološkom tako i na profesionalnom te financijskom planu (često odustaju od plaćenog rada ili su prisiljeni reducirati broj radnih sati), kao i na međusobne odnose s obitelji i širom socijalnom okolinom (Aguglia i sur., 2000).

6. Narušeno psihofizičko funkcioniranje njegovatelja problem je s kojim se suočavaju u njezi osobe oboljele od demencije, a prepoznato je u kategorijama: sagorijevanje, problemi sa spavanjem i narušeno fizičko zdravlje. Povezanost narušenog fizičkog i psihičkog zdravlja te obnašanja uloge neformalnog njegovatelja vrlo je visoka (Schulz i Sherwood, 2008). Romero-Moreno i suradnici (2014) navode kako se zbog visokih zahtjeva vezanih uz brigu za oboljelog člana njegovateljstvo smatra kao izrazito stresnom dužnosti. Sagorijevanje je prepoznato u sljedećim izjavama ispitanika: Netko bi trebao zapravo biti cijelo vrijeme s njom i to je dodatno opterećenje, psihički. (I3); ...s njim sam non stop, mora stalno biti pod kontrolom i to mi je jako opterećujuće, umorna sam od toga... ne mogu više! (I4); Osim što sam fizički izložena, psihički je puno teže. To je najteži napor. Stariji ljudi su posesivni $i$ onda cijelo vrijeme traže pažnju. Vi imate i svojih obaveza i neki svoj život bi htjeli a oni jednostavno ne razumiju. (I3); Živci su mi nastradali. Jako sam iscrpljena i svu energiju mi je mama posisala. I sad sam stvarno na rubu snaga. (I4); Nekad imam osjećaj da ću puknuti. (I7). Njegovateljsko sagorijevanje utječe na zdravlje kako njegovatelja tako i osobe o kojoj se njegovatelj skrbi. Njegovateljsko sagorijevanje definirano je kao višedimenzionalni odgovor na percipirani stres koji proizlazi iz brige za oboljele osobe, a narušava fizičko, psihološko, emocionalno te funkcionalno zdravlje njegovatelja (Kim i sur.,
2011). Nekoliko je faktora povezano sa sagorijevanjem njegovatelja, uključujući tipove zadataka koje je potrebno provesti, razinu potpore i sposobnost da se nose s narušenim kognitivno-bihevioralnim funkcioniranjem oboljelog. Tako se nepostojanje resursa zaštite i podrške neformalnim njegovateljima pokazalo kao ozbiljan rizik za pojavu sagorijevanja (Kim i sur., 2011). Moon i Dilworth-Anderson (2011) navode da je puno veća razina sagorijevanja zabilježena kod neformalnih njegovatelja koji se skrbe za osobe oboljele od demencije, u odnosu na ostale njegovatelje. Novija istraživanja ukazuju na važnost edukacije o specifičnostima tijeka ove bolesti kao važnom faktoru smanjenja skrbničkog stresa (Scott, 2013). Problemi sa spavanjem također dovode do narušavanja psihofizičkog funkcioniranja: $M o z ̌ d a$ trebam spavati duže. Ustajem se nekoliko puta po noći, kad idemo na wc, promijenimo pidžamu jer se on jako znoji (I4); Puno puta ne mogu spavati po noći. Kad je njoj teško i meni je, ipak smo mi emotivno povezani... To mi bude teško ali nekako to prođe. (I7). Kad se ona između 2 i 5 nekoliko puta probudi, onda se i ja moram ustati. (I9); ...teško spavam. (I10). Istraživanje D'Aoust i suradnika (2013) pokazuje da samo 8,3\% njegovatelja ima 7 sati sna. Potreba za stalnom budnošću identificirana je kao jedan od glavnih izazova njegovatelja što može prouzročiti brojne negativne posljedice za njihovo zdravlje. U prilog tome govori i podatak kako loš san može predstavljati podlogu za nastanak depresivnih simptoma (D'Aoust i sur., 2013). Prethodno navedeni problemi dovode do narušavanje fizičkog zdravlja što potvrđuju sljedeće izjave ispitanika: ... ali ono što ja vidim je dijagnoza od prije par mjeseci - štitnjača. E sad, da li je povezano sad s tim, ne znam. (I2); Da, imam češće migrene, nekakve glavobolje. To sam prije znala imati ali jako rijetko ali sada su u zadnjih dvije godine dosta česte. (I5). Obiteljski njegovatelji osoba oboljelih od demencije suočeni su s povećanim rizikom od raznih zdravstvenih problema, uključujući kardiovaskularne probleme, oslabljeni imunitet, siromašniji imunološki odgovor na cjepivo, sporije zacjeljivanje rana, više razine kroničnih stanja (npr. dijabetes, artritis, čirevi i anemija), više posjeta liječniku i korištenje lijekova na recept, smanjeni angažman u preventivnim zdravstvenim pothvatima kao što su vježbe i veća sklonost pušenju, konzumaciji alkohola te lošijem spavanju (Brodaty i Donkin, 2009). 
Mnogi od navedenih zdravstvenih problema uzrokovani su time što skrbnici nemaju vremena za sebe, ne hrane se pravilno, ne vježbaju, ne relaksiraju se i ne odmaraju (Juozapavicius i Weber, 2001; prema Laklija i sur., 2009).

Iz navedenih rezultata istraživanja možemo vidjeti da su obiteljski njegovatelji prepušteni "sami sebi" te se iz iznesenih problema jasno vide njihove nezadovoljene potrebe koje mogu poslužiti kao smjernice za unapređenje podrške i pomoći. Ovdje valja napomenuti da se radi o njegovateljima čiji su supružnici, odnosno roditelji tijekom dana u Dnevnom centru, a poslijepodne se vraćaju doma. Nedostaje im mreža socijalne podrške kao i vrijeme u kojem bi se mogli posvetiti svojim potrebama, hobijima. To je vidljivo iz njihovih odgovora da nemaju dovoljno vremena za obitelj, prijatelje, slobodne aktivnosti. Ako uzmemo u obzir da je šest naših ispitanika u radnom odnosu, dok je njihov roditelj u Dnevnom centru, sve preostalo slobodno vrijeme nakon rada posvećeno je bolesnom roditelju. Tijekom vikenda ne postoji dežurstvo u Dnevnim centrima što bi svakako bilo važno osigurati za obiteljske njegovatelje da "predahnu" i odmore se. Vjerojatno je i nemogućnost predaha kroz duži vremenski period pridonijela narušenom psihofizičkom zdravlju (neki su njegovatelji u toj ulozi 8-10 godina!). Također se može razmotriti mogućnost skraćenog radnog vremena za njegovatelje ili novčana naknada, što je svakako jeftinija i humanija mjera u odnosu na institucionalizaciju (koju njegovatelji ističu kao nedostupnu). Istaknuta je potreba za edukacijom o tijeku bolesti, načinu kako komunicirati s oboljelim i strategijama suočavanja sa stresom koje su u dosadašnjim istraživanjima pokazale dobre rezultate u smanjenju njegovateljskog tereta kao i bolje kvalitete života kod oboljelih i njihovih njegovatelja (Scott, 2013; Savundranayagam i sur. 2011; Martín-Carrasco i sur. 2009).

\section{ZAKLJUČAK}

Ovim istraživanjem identificirani su brojni ozbiljni problemi s kojima se suočavaju neformalni njegovatelji osoba oboljelih od demencije. Naime radi se o novim zadacima njegovateljske uloge koji za njegovatelja predstavljaju veliku prilagodbu i reorganizaciju dotadašnjeg života na svim područjima: cjelodnevna briga o oboljeloj osobi, dodatne kućanske obveze, sukob uloga, otežana komunikacija kroz razgovor o besmislenim temama i/ili nemogućnost sporazumijevanja s oboljelim. Suočeni su i s nedovoljnom socijalnom osviještenosti okoline jer je po njihovu mišljenju javnost nedovoljno educirana te uočavaju i nedostatak senzibiliteta za svoje probleme. Isto tako neformalni njegovatelji suočeni su s problemima na razini sustava budući da nemaju mogućnost institucionalnog smještaja za oboljelog, kao ni mogućnost dobivanja podrške i pomoći od stručnjaka jer su $i$ oni nedovoljno educirani. No treba istaknuti da se često kao jači razlog institucionalizacije navodi sagorijevanje njegovatelja nego sama težina bolesti oboljelog (Alzheimer's Association, 2011). Kao posljedicu zahtjevne skrbi navode nedostatak vremena za slobodne aktivnosti, prijatelje i obitelj što rezultira socijalnom izolacijom. Konačno, kao posljedica zahtjevnosti uloge bez adekvatne pomoći i podrške narušeno je psihofizičko funkcioniranje koje se ogleda u sagorijevanju, problemima sa spavanjem te narušenom tjelesnom zdravlju. Svi navedeni problemi ukazuju na vrlo težak položaj obiteljskih neformalnih njegovatelja.

Kvalitativnim istraživanjem dobili smo jasno definirane probleme s kojima se njegovatelji susreću, odnosno njihove neprepoznate potrebe od strane stručnih službi kao i zajednice u kojoj žive. $\mathrm{Na}$ većinu navedenih problema možemo odgovoriti već spomenutim intervencijama vezanim uz bolju edukaciju samih njegovatelja o tijeku bolesti i suočavanju s problematikom koju bolest nosi. Također je važno razmotriti na koji način obiteljski njegovatelji trebaju biti prepoznati od strane donosioca politika skrbi kao vidljivi pružatelji usluga, ali i kao partneri u kreiranju strategija, usluga i razvijanju standarda za specifične kategorije korisnika. $\mathrm{U}$ daljnjim istraživanjima trebalo bi svakako obuhvatiti veći broj sudionika (posebno onih koji imaju dugi njegovateljski staž) te njegovatelje iz ruralnih područja s ciljem prepoznavanja specifičnih potreba i pružanja adekvatne pomoći i podrške. Budući da obiteljski njegovatelji najčešće preuzimaju kompletnu skrb o svojim oboljelim članovima, trebamo se pobrinuti za njih, odnosno kao društvo trebamo prepoznati i vrednovati njihov angažman u skrbi za najosjetljivije članove društva te ih adekvatnom "njegom" osnaživati i podržati u toj ulozi. 


\section{LITERATURA}

Aguglia, E., Onor, M. L., Trevisiol, M., Negro, C., Saina, M. \& Maso, E. (2000): Stress in the caregivers of Alzheimer's patients: An experimental investigation in ltaly. American Journal of Alzheimer's Disease and Other Dementias, 19(4), 248-252.

Alzheimer's Association (2011): 2011 Alzheimer's Diseases Facts and Figures. Alzheimer's \& Dementia, 7(2), 208-244.

Bastawrous, M. (2013): Caregiver burden: A critical discussion. International Journal of Nursing Studies, 50(3), 431-441.

Braun, V. \& Clarke, V. (2006): Using tematic analysis in psychology. Qualitative research in Psychology, 3(2), 77-101.

Brodaty, H. \& Donkin, M. (2009): Family caregivers of people with dementia. Dialogues in Clinical Neurosciences, $11(2), 217-228$.

Čudina-Obradović, M. \& Obradović, J. (2006): Psihologija braka i obitelji. Zagreb: Golden marketing - Tehnička knjiga.

D’Aoust, R. F., Brewster, G. \& Rowe, M. A. (2015): Depression in informal caregivers of persons with dementia. International Journal of Older People Nursing, 10(1), 14-26.

Etters, L., Goodall, D. \& Harrison, B. E. (2008): Caregiver burden among dementia patient caregivers: A review of the literature. Journal of the American Academy of Nurse Practitioners, 20(8), 423-428.

Folnegović-Šmalc, V., Uzun, S., Kozumplik, O., Folnegović-Grošić, P., Henigsberg, N., Makarić, G., Mihanović, M., \& Mimica, N. (2002): Farmakoterapija Alzheimerove bolesti. Medicus, 11(2), 217-222.

Gillham, B. (2005): Research Interviewing: The Ranges of Techniques. Maidenhead: Open University Press.

Jedvaj, S., Štambuk, A. \& Rusac, S. (2014): Demografsko starenje stanovništva i skrb za starije osobe u Hrvatskoj. Socijalne teme, 1(1), 135-154.

Kim, H., Chang, M., Rose, K. \& Kim, S. (2011): Predictors of caregiver burden in caregivers of individuals with dementia. Journal of Advanced Nursing, 68(4), 846-855.

Laklija, M., Milić Babić, M. \& Rusac, S. (2009): Neki aspekti skrbi o članu obitelji oboljelom od Alzheimerove bolesti. Ljetopis socijalnog rada, 16(1), 69-89.

Martín-Carrasco, M., Martin, M. F., Valero, C. P., Millán, P. R., García, C. I., Montalbán, S. R., Vilanova, M. B. (2009): Effectiveness of a psychoeducational program in the reduction of caregiver burden in Alzheimer's disease patients' caregivers. International Journal of Geriatric Psychiatry, 24(5), 489-499.

Milas, G. (2005): Istraživačke metode u psihologiji i u drugim društvenim znanostima. Jastrebarsko: Naklada Slap.

Milić Babić, M., Laklija, M. \& Rusac, S. (2014): Neke odrednice zadovoljstva socijalnom podrškom njegovatelja osoba oboljelih od Alzheimerove bolesti. Revija za socijalnu politiku, 21(2), 201-218.

Mimica, N. \& Presečki, P. (2010): Current treatment options for people with Alzheimer's disease in Croatia. ChemicoBiological Interactions, 187(1-3), 409-410.

Moon, H. \& Dilworth-Anderson, P. (2014): Baby boomer caregiver and dementia caregiving: findings from the National Study of Caregiving. Age and Ageing, 44(2), 300-306.

Podgorelec, S., Klempić, S. (2007): Starenje i neformalna skrb o starim osobama u Hrvatskoj. Migracijske i etničke teme, 23(1-2), 111-134.

Poredoš, D. (2003): Alzheimerova bolest i obitelj. Ljetopis Studijskog centra socijalnog rada, 10(2), 243-254.

Puljak, A., Perko, G., Mihok, D., Radašević, H. \& Tomek Roksandić, S. (2005): Alzheimerova bolest kao gerontološki javnozdravstveni problem. Medicus, 14(2), 229-235.

Rapić, M., Mačešić, B. \& Rapić Mrgan, M. (2014): Obitelj kao osnovna jezgra palijativne skrbi - prikaz slučaja. Medicina Familiaris Croatica, 22(1), 26-34. 
Rusac, S., Laklija, M. \& Milić Babić, M. (2012): Strategije suočavanja članova obitelji oboljelih od Alzheimerove bolesti. Hrvatska revija za rehabilitacijska istraživanja, 48(2), 87-96.

Savundranayagam, M. Y., Montgomery, R. J., Kosloski, K., \& Little, T. D. (2011): Impact of a psychoeducational program on three types of caregiver burden among spouses. International Journal of Geriatric Psychiatry, 26(4), $388-396$.

Schaie, K. W., Willis, S. L. (2001): Psihologija odrasle dobi i starenja. Jastrebarsko: Naklada Slap.

Scott, C. B. (2013): Alzheimer's disease caregiver burden: Does resilience matter? Journal of Human Behavior in the Social Environment, 23(8), 879-892.

Sorrell, J. M. (2006): Listening in thin places: Ethics in the care of persons with Alzheimer's disease. Advances in Nursing Science, 29(2), 152-160.

Škrbina, D. \& Radić, S. (2010): Kreativno izražavanje kao sredstvo potpomognute komunikacije kod osoba oboljelih od Alzheimerove bolesti. Ljetopis socijalnog rada, 17(2), 263-27.

WHO (2017): Dementia. Posjećeno 20. 4. 2018. na mrežnoj stranici: http://www.who.int/mediacentre/factsheets/ fs362/en/

Žganec, N., Rusac, S. \& Laklija, M. (2008): Trendovi skrbi za osobe starije životne dobi u Republici Hrvatskoj i zemljama Europske unije. Revija za socijalnu politiku, 15(2), 171-188.

\section{PROBLEMS OF INFORMAL (FAMILY) CAREGIVERS IN THE CARE OF PEOPLE WITH DEMENTIA - A QUALITATIVE APPROACH}

Abstract: Alzheimer's disease, as the most common form of dementia, is a progressive, incurable condition that can lead to total dependence on others. The whole family, especially the family member who serves as caregiver of a patient, faces many problems and is in a very difficult situation. By taking over the demanding role of care for the family member, the carer often becomes a "victim of the disease" who needs to find ways to shoulder everything that the disease brings. Studies outside Croatia show that some interventions assist caregivers in their role, such as knowledge of the disease process, knowledge of nutrition and nursing of the affected person, knowledge of caregiver-related stress management, and instructions on how to address the problems associated with the patient's changed behaviour. In order to gain insight into the problems encountered by informal carers in the care of a member of the family with dementia in Croatia, we examined their experiences. The method used for this qualitative research was a semi-structured interview. The results of this research suggest that informal caregivers are faced with demanding tasks of caring, difficulties in communication with the sick, system-level problems, social isolation and disrupted psychophysical functioning. The work emphasises the importance of educating informal caregivers about different aspects of care with the aim of facilitating a caring role, expertise in working with patients, and informing and sensitising the local community and society about the needs of informal caregivers.

Key words: Alzheimer's Disease, Dementia, Family, Informal Caregivers 